\title{
The Evolving Role of Environmental Rights in Climate Change Litigation
}

\author{
Brian J PRESTON \\ Chief Judge of the Land and Environment Court of New South Wales, \\ Australia \\ chiefjudgeassociate@courts.nsw.gov.au
}

\begin{abstract}
Litigation raising climate change issues has increased in the number and types of cases across a growing number of national and international jurisdictions. An emergent trend is litigation that invokes particular legal rights to address climate change issues. Referred to collectively in this article as 'environmental rights,' these include rights established under the public trust doctrine, as well as within the realms of constitutional and human rights, including the right to life and right to a quality environment. This article surveys the development of climate change litigation - in various jurisdictions around the world - in which parties have sought to invoke these environmental rights. In addition to examining how climate change litigation has adapted rightsbased claims made in earlier, more traditional litigation, this article reviews recent significant cases and examines how this growing body of case law is contributing to an expansion in the content of fundamental rights in the climate change context.
\end{abstract}

\section{Keywords}

climate change - climate change litigation - public trust doctrine - constitutional rights - environmental rights - human rights

Climate change is severely impacting the planet and its people. Governments have responded, in varying degrees and with varying effectiveness, to the climate crisis by making laws and policies to mitigate the causes and adapt to

(C) BRIAN J PRESTON, 2018 | DOI:10.1163/24686042-12340030

This is an open access article distributed under the terms of the prevailing CC-BY-NC License at the time of publication. 
the consequences of climate change. Industries primarily responsible for causing climate change, such as the carbon extractors and carbon emitters, have generally taken less action. Civil society groups and individuals have turned to litigation to remedy and redress the inaction and ineffective action by government and industry. ${ }^{1}$ The growing number of cases raising climate change issues can be categorised in various ways. For instance, in its global survey of almost 900 cases, ${ }^{2}$ UN Environment identified several emerging trends in climate change litigation by reference to the purpose of the case, including seeking to enforce governments' legislative and policy commitments and establishing liability for failures (or efforts) to adapt to climate change. ${ }^{3}$ Another method of identification is by categorising climate change litigation according to the sources of law underpinning the cases. In this regard, several commentators have examined an emergent trend of increasing reliance on rights in climate change litigation around the world. ${ }^{4}$

Reliance on rights to secure environmental or social outcomes is of course not a new phenomenon. ${ }^{5}$ At an international level for instance, the European

1 Many reviews of the climate change litigation have been undertaken, including: UN Environment, The Status of Climate Change Litigation: A Global Review (United Nations Environment Programme, 2017); MB Gerrard and M Wilensky, "The role of the national courts in GHG emissions reductions' in M Faure (ed), Elgar Encyclopaedia of Environmental Law (Edward Elgar 2016); HM Osofsky and J Peel, Climate Change Litigation: Regulatory Pathways to Cleaner Energy (CUP 2015); BJ Preston, 'Climate Change Litigation (Part 1)' (2011) 5 Carbon and Climate Law Review 3; BJ Preston, 'Climate Change Litigation (Part 2)' (2011) 5 Carbon and Climate Law Review 244; M Wilensky, 'Climate Change in the Courts: An Assessment of NonU.S. Climate Litigation' (2015) 26 Duke Environmental Law and Policy Forum 131; D Markell \& JB Ruhl, 'An Empirical Assessment of Climate Change in the Courts: A New Jurisprudence or Business as Usual?' (2012) 64(1) Florida Law Review 15.

2 See UN Environment ( $\left.\begin{array}{ll}n & 1\end{array}\right)$ 11, where it is pointed out that as of March 2017, just over $90 \%$ of these cases were heard in common law jurisdictions, namely USA, Australia, the United Kingdom, New Zealand, Canada, and Ireland. The next major jurisdiction was the EU, with 40 cases submitted to the European Court of Justice.

3 See further discussion, UN Environment (n 1 ) $14 \mathrm{ff}$.

4 See eg J Peel and H Osofsky, 'A Rights Turn in Climate Change Litigation?' (2018) 7(1) Transnational Environmental Law 37.

5 See eg A Grear and LJ Kotzé (eds), Research Handbook on Human Rights and the Environment (Edward Elgar 2015); R Pavoni, 'Environmental Jurisprudence of the European and InterAmerican Courts of Human Rights: Comparative Insights' in B Boer (ed), Environmental Law Dimensions of Human Rights (OuP 2015) 69; DR Boyd, The Environmental Rights Revolution: A Global Study of Constitutions, Human Rights, and the Environment (U BC Press 2012); D Shelton, 'Draft Paper on Human Rights and Environment: Past, Present and Future Linkages and the Value of a Declaration,' High Level Expert Meeting on the New Future of Human Rights and Environment: Moving the Global Agenda Forward (UNEP and оHCHR 2009); MR Anderson, 'Human Rights Approaches to Environmental Protection: An Overview' in A Boyle and MR Anderson (eds), Human Rights Approaches to Environmental Protection (ouP 1996); 
Court of Human Rights has an established practice of interpreting a number of substantive human rights as incorporating environmental considerations. ${ }^{6}$ Accordingly, numerous claimants have taken action to remedy interferences with various human rights, including the right to life, right to a fair trial and right to respect for family and private life, resulting from environmental hazards, such as air pollution. ${ }^{7}$ Other international human rights instruments contain an express substantive human right to a healthy environment. ${ }^{8}$ In addition to these substantive international rights, the 1998 Aarhus Convention has long recognised three key procedural environmental rights, namely, the right to public participation, and the rights of access to information and justice. ${ }^{9}$ At a national level, a number of courts-particularly in the South Asia region-have been proactive in interpreting the right to life (mostly found in a country's constitution) as involving a right to a 'qualitative life ... free from environmental hazards'10 or, more simply, a right to a quality environment. The courts have restrained governmental action and remedied

FZ Ksentini, Review of further developments in fields with which the sub-commission has been concerned: Human Rights and the Environment, Final Report prepared by Special Rapporteur, UN Doc E/CN.4/Sub.2/1994/9 (6 July 1994); D Shelton, 'Human Rights, Environmental Rights, and the Right to Environment' (1991) 28 Stanford Journal of International Law 103.

6 For a comprehensive discussion regarding the development of this Court's jurisprudence see Council of Europe, Manual on Human Rights and the Environment (2nd edn, COE Publishing 2012).

7 Ibid.

8 See eg African Charter on Human and Peoples' Rights (adopted 27 June 1981, entered into force 21 October 1986) 21 ILM 59 (1981) art 24; Organization of American States (OAS), Additional Protocol to the Inter-American Convention on Human Rights in the Area of Economic, Social and Cultural Rights (adopted 17 November 1988, entered into force 16 November 1999) A-52, OAs Treaty Series No 69, art 11; League of Arab States, Arab Charter of Human Rights (adopted 22 May 2004, entered into force 15 March 2008), reprinted in 12 International Human Rights Reports 893 (2005) art 38.

9 Convention on Access to Information, Public Participation in Decision-Making and Access to Justice in Environmental Matters (adopted 25June 1998, entered into force 30 October 2001) 2161 un ts 447. See also in-depth discussion in J Ebbesson et al, The Aarhus Convention: An Implementation Guide, ECE/CE P/72 (2nd edn, United Nations 2013).

10 Farooquev Government of Bangladesh (Supreme Court of Bangladesh, WP No 891 of 1994, 15 July 2001) 17. See also discussion in J Razzaque, 'Human Rights and the Environment: The National Experience in South Asia and Africa' (Background Paper No 4, Joint UnEPонснR Expert Seminar on Human Rights and the Environment, Geneva, 14-16 January 2002). 
governmental inaction that has infringed citizens' right to live in a clean and healthy environment. ${ }^{11}$

In the past, claims such as those mentioned above mostly did not expressly raise climate change issues. In recent years, this has changed, with the recognition that climate change affects the enjoyment of human rights. ${ }^{12}$ Ultimately the growing recognition of role of human rights in dealing with climate change issues was recognised in the 2015 Paris Agreement. ${ }^{13}$ In turn, this has engendered greater reliance on rights, or as described by Peel and Osofsky, 'a rights turn,' in climate change litigation. ${ }^{14} \mathrm{~A}$ recent decision of the Inter-American Court of Human Rights, for example, recognised the 'irrefutable relationship' between the protection of the environment and human rights because environmental degradation and climate change affect the enjoyment of human rights. ${ }^{15}$ Similarly, in recent litigation in the South Asia region, courts have considered claims expressly related to action or inaction of governments to mitigate the causes of climate change, such as to regulate the sources and sinks of greenhouse gases, or to adapt to the consequences of climate change, including increased sea levels, storms, floods, droughts or bushfires. The basis of the litigation remains the constitutional rights, including the right to life, that are infringed, but the environmental hazards affecting those rights are expressly identified as the causes and consequences of climate change. ${ }^{16}$ This

11 See eg Indian Council for Enviro-Legal Action v Union of India 1996 (5) SCC 281 (Indian Supreme Court).

12 See eg K Davis et al, 'The Declaration on Human Rights and Climate Change: A New Legal Tool for Global Policy Change' (2017) 8 Journal of Human Rights and the Environment 217; JH Knox, 'Human Rights Principles and Climate Change' in KR Gray, R Tarasofsky and C Carlarne (eds), The Oxford Handbook of International Climate Change Law (oup 2016); 'Understanding Human Rights and Climate Change,' Submission of the Office of the High Commissioner for Human Rights to the 21st Conference of the Parties to the United Nations Framework Convention on Climate Change (27 November 2015); International Bar Association, Achieving Justice and Human Rights in an Era of Climate Disruption (2014); S McInerney-Lankford, M Darrow, and L Rajamani, Human Rights and Climate Change A Review of the International Legal Dimensions (The International Bank for Reconstruction and Development and The World Bank 2011).

13 The Paris Agreement under the United Nations Framework Convention on Climate Change (adopted 12 December 2015, entered into force 4 November 2016) 55 ILM 740.

14 Peel and Osofsky (n 4).

15 Inter-American Court of Human Rights (Official Summary of Advisory Opinion OC-23/17 of 15 November 2017) 2; Inter-American Court of Human Rights (Advisory Opinion OC-23/17 of 15 November 2017) 21-22.

16 See for example Asghar Leghari v Federation of Pakistan (Lahore High Court, WP No 25501/2015, 14 September 2015); Segovia v Climate Change Commission (GR No. 211010, 7 March 2017, Supreme Court of the Philippines); and Pandey v India (National Green Tribunal of India, Original Application No 187 of 2017, Petition filed 25 March 2017). 
trend of litigation in the South Asia region, of moving from reliance on general constitutional rights, such as the right to life, to particular rights concerning the environment, such as the right to a quality environment, is discernible elsewhere in the world. May and Daly, for example, record the exponential growth in the number of countries that have recognised the right to a quality environment. ${ }^{17}$ With this increasing constitutional recognition of a right to a quality environment has been an increase in litigation in these countries claiming that governmental action and inaction has infringed this right.

More recently, claimants are focussing on governmental action and inaction regarding climate change mitigation and adaptation. ${ }^{18}$ Another illustration of a 'rights turn' in climate change litigation is the renewed reliance on the public trust doctrine. The public trust doctrine, which has been incorporated into the common law and civil law, protects common natural resources held by the government in trust for the benefit and use of the citizens. ${ }^{19}$ The communal natural resources sought to be protected in early environmental litigation were mostly submerged and submersible lands, including waterways and lakes. The 'turn' came when claimants expanded the communal natural resources sought to be protected to include the atmosphere. Claimants argued that governments have a duty to protect the atmosphere by taking action to regulate and restrict greenhouse gas emissions that contribute to climate change. The claimants sought to enforce their rights, as beneficiaries of the public trust, to use and enjoy a clean and healthy atmosphere and stable climate. ${ }^{20}$

Against this backdrop, this article examines more closely the role of environmental rights in climate change litigation, to map the contours of relevant jurisprudence that has developed around the world. To this end, it surveys climate change litigation in a variety of countries that has been based on the infringement of some right. Relevant litigation has been grouped in three categories depending on the right relied upon: (i) the rights of the public under the public trust doctrine; (ii) constitutional rights, particularly the right to life and

17 See generally JR May and E Daly, Global Environmental Constitutionalism (Cambridge University Press, 2014); JR May and E Daly, Global Judicial Handbook on Environmental Constitutionalism (2nd edition, UN Environment, 2018). See also earlier comprehensive studies such as DR Boyd, The Environmental Rights Revolution: A Global Study of Constitutions, Human Rights, and the Environment (U ВC Press 2012).

18 See, for example, Foster $v$ Washington Department of Ecology (Wash Super Ct, 14-2-252951-SEA, 19 November 2015); Juliana $v$ USA (D Or, 6:15-cv-1517-TC, 8 April 2016); and Future Generations $v$ Ministry of the Environment and others (Colom Sup Ct, 11001-22-03-000-2018oo319-01, 5 April 2018).

19 See JL Sax, 'The Public Trust Doctrine in Natural Resource Law: Effective Judicial Intervention' (1970) 68 Michigan Law Review 471.

$20 \quad$ Peel and Osofsky (n 4) 55-58. 
the right to a quality environment; and (iii) human rights. This article refers to these rights collectively as 'environmental rights.' Environmental rights can be defined as the legal entitlements of individuals or groups to receive and enjoy environmental outcomes and to enforce the reciprocal obligations of governments, companies or individuals to provide these environmental outcomes, or not to interfere with these environmental outcomes. The right to a clean and healthy environment is a clear example of an environmental right. Human rights, such as the right to life, will also be environmental rights where courts construe these rights as depending on certain environmental conditions, such as clean air or clean water. Similarly, the public trust doctrine, although not expressed in the language of rights, establishes the public's right to access, use and enjoy common natural resources, the reciprocal obligations of governments to protect and maintain these resources and the public's right to access, use and enjoy these resources.

\section{Rights under the Public Trust Doctrine}

The public trust doctrine has its origins in the Roman law property concept of res communis. These are things which, by their nature, are part of the commons that all humankind has a right in common to access and use, such as the air, running water, the sea and the shores of the sea, and that cannot be appropriated to private ownership. Ownership of these common natural resources is vested in the state as public trustee of a public trust for the benefit of the people. The State, as trustee, is under a fiduciary duty to deal with the trust property, being the communal natural resources, in a manner that is in the interests of the general public, who are the beneficiaries of the trust. ${ }^{21}$ The source of this duty can be the common law, statute law or constitutional law. In the context of climate change, citizens of countries, or states, provinces or territories within a country, have sought to enforce their rights, as beneficiaries of the public trust, to require governments to protect the atmosphere by mitigating greenhouse gas emissions. To do so, litigants have had to argue that the common natural resources held in trust on behalf of the public include the natural resource of the atmosphere, and that the duties of government under the public trust include the duty to protect the atmosphere by regulating greenhouse gas emissions in the jurisdiction.

21 See JL Sax, 'The Public Trust Doctrine in Natural Resource Law: Effective Judicial Intervention' (1970) 68 Michigan Law Review 471. 


\subsection{Public Trust Litigation in the United States}

Most of the atmospheric public trust litigation has been in the United States. One of the first cases was Kanukv State of Alaska. ${ }^{22}$ The plaintiffs, Alaskan children, claimed that the State of Alaska had violated the public trust doctrine under the Alaskan Constitution (Article VIII) by failing to take steps to protect the atmosphere from the effects of climate change. The Court upheld the plaintiffs' standing to bring the proceedings and the justiciability of the plaintiffs' claims for a declaratory judgment that the atmosphere was a public trust resource. However, the Court found these claims failed to present an actual controversy appropriate for judicial determination. The Court noted that 'past application of public trust principles has been as a restraint on the State's ability to restrict public access to public resources, not as a theory for compelling regulation of those resources. ${ }^{23}$

In Sanders-Reed v Martinez, ${ }^{24}$ the New Mexico Court of Appeal affirmed the trial court decision and ruled that courts could not require the State of New Mexico to regulate greenhouse gas emissions based on the public trust doctrine. The common law doctrine was not an available cause of action because a public trust obligation to protect natural resources, including the atmosphere, had been incorporated into the New Mexico Constitution (Article Xx, Section 21) and the State Air Quality Control Act, and the common law now had to yield to the governing statutes. In Chernaikv Brown, ${ }^{25}$ the youth plaintiffs argued that the public trust doctrine compelled the State of Oregon to take action to establish and enforce limitations on greenhouse gas emissions to reduce carbon dioxide in the atmosphere. The Oregon Circuit Court ruled that the State's public trust doctrine applied only to submerged and submersible lands and not to the atmosphere. The Court questioned 'whether the atmosphere is a 'natural resource' at all, much less one to which the public trust doctrine applies.' The Court further declared that the State does not have a 'fiduciary obligation to protect submerged and submersible lands from the impacts of climate change,' but rather the public trust doctrine restricts the ability of the State to entirely alienate such lands. The plaintiffs appealed the decision, which is still pending.

The breakthrough in atmospheric public trust litigation came in the case of Juliana $v$ USA. The plaintiffs, including Juliana, were children organised by

$22 \quad 335$ P 3 d 1088 (Sup Ct Alaska, 2014).

23 Ibid 1102; Sabin Center for Climate Change Law, 'Kanuk v. Alaska' (Climate Change Litigation Database, 2014) <http://climatecasechart.com/case/kanuk-v-alaska/>.

$24 \quad 350$ P $3 \mathrm{~d} 1221$ (NM Ct App, 2015).

25 Or Cir Ct, 16-11-09273, 11 May 2015. 
an environmental non-governmental organisation, Our Children's Trust. The plaintiffs sued the US government in the US District Court for the District of Oregon in 2015. The plaintiffs sought relief from governmental action and inaction in regulating carbon dioxide pollution, allegedly resulting in catastrophic climate change and causing harm to the plaintiffs. The action was founded upon the alleged violation of the plaintiffs' explicit and implicit constitutional rights and the public trust doctrine. The US government and various industry interveners sought to summarily dismiss the action on various grounds, including that the public trust doctrine does not provide a cognizable federal cause of action because the Supreme Court had foreclosed such actions against the federal government. A magistrate judge in the District of Oregon recommended that the District Court decline to dismiss the action. The magistrate judge found that given the Environment Protection Agency's duty to protect public health from airborne pollutants and the federal government's deeply ingrained public trust duties, there was a sufficient possibility that the public trust doctrine provided 'some substantive due process protections for some plaintiffs within the navigable water areas of Oregon. ${ }^{26}$ On 10 November 2016, the District Court declined to summarily dismiss the action. In so doing, the Court adopted the findings and recommendation of the magistrate judge. The Court rejected the defendants' four arguments that the public trust doctrine was inapplicable. In summary, the Court held that:

(1) it was unnecessary to determine whether the atmosphere is a public trust asset because the plaintiffs also alleged public trust violations in connection with the territorial sea;

(2) the public trust doctrine is not limited to state governments; the federal government also holds public assets in trust for the people;

(3) public trust obligations cannot be legislated away; and

(4) the plaintiffs' public trust rights both predate the Constitution and are secured by it (in particular, the Fifth Amendment provides the right of action). ${ }^{27}$

The federal defendants and the interveners both filed a motion for the District Court to certify an interlocutory appeal of the order of 10 November 2016. The federal defendants also filed a motion to stay the litigation. The motions were denied on all of the six grounds of appeal. On the political question, the Court 'emphatically rejected' the suggestion that the topic of climate change is non-justiciable. ${ }^{28}$ On the breadth of claims and vast scope of relief sought, the Court held that this was hypothetical and ignored the trial court's ability

\footnotetext{
26 Juliana v USA (D Or, 6:15-cv-1517-TC, 8 April 2016).

27 Juliana $v$ USA 217 F Supp 3d 1224 (D Or, 2016).

28 Juliana v USA (D Or, 6:15-cv-1517-TC, 1 May 2017) 8.
} 
to fashion reasonable remedies based on evidence. On due process, the Court held that any appeal would be premature, because the taking of evidence will flesh out the issues, and the case involves a mixed question of law and fact that mandates an opportunity to develop the record. On the public trust, the Court held that the federal public trust doctrine has not been extinguished (despite being relatively dormant since the 19th century). On standing, the Court held that the defendants admitted that anthropogenic climate change is harming the environment, making it increasingly less habitable and causing deleterious effects on physical and mental health. It found that these are concrete, particularised, actual or imminent injuries to the plaintiffs and the fact that vast numbers of people will suffer these injuries does not negate standing. On the controlling question of law, the Court noted that this ground applies to purely legal questions. It did not apply in the present case where there is a mixed question of law and fact. The District Court granted motions by three trade groups to withdraw from the lawsuit and set the trial to begin on 5 February 2018. ${ }^{29}$ This did not occur because of an appeal by the federal government.

In June 2017, the federal government petitioned the Ninth Circuit of the Court of Appeals for a writ of mandamus (an administrative law remedy compelling performance of a legal obligation) to review the District Court's denial of the motions to dismiss the plaintiffs' case. On 7 March 2018, the Court of Appeals denied the petition, finding: 'The issues that the defendants raise on mandamus are better addressed through the ordinary course of litigation. ${ }^{30}$ The Court of Appeals rejected the defendants' argument that mandamus was their only means of obtaining relief from potentially burdensome discovery because there had not been any discovery orders or motions compelling discovery in the case thus far. ${ }^{31}$ The Court of Appeals also found that holding the trial would not threaten the separation of powers as it would not unreasonably burden President Trump or executive branch officials and agencies who were listed as parties to the proceeding. ${ }^{32}$ Further applications to stay the proceedings had been dismissed, but yet another application for a temporary stay was filed in November 2018,33 precluding the District Court from setting a trial hearing date. ${ }^{34}$

29 Juliana v USA (D Or, 6:15-cv-1517-TC, 28 June 2017).

3o Juliana v USA (9th Cir, 17-71692, 7 March 2018) 9-10.

31 Ibid 10.

32 Ibid 13 .

33 USA v US District Court for District of Oregon (9th Cir, 18-71928, 16 July 2018); USA v US District Court for District of Oregon (9th Cir, 18-71928, 20 July 2018); USA v US District Court for District of Oregon (US Supreme Court, 18A65, 30 July 2018). The original trial date was set on 29 October 2018. See Juliana $v$ USA (D Or, 6:15-cv-1517, 12 April 2018). 
Another case upholding the atmospheric public trust is Foster $v$ Washington Department of Ecology. ${ }^{35}$ A group of eight children, including Foster, petitioned the Washington Department of Ecology to adopt a proposed rule mandating a particular State greenhouse gas emission cap that was consistent with current scientific assessments of the measures required to prevent global warming, on the basis that the State of Washington has a constitutional obligation to protect and manage common natural resources under the public trust doctrine. ${ }^{36}$ The Department denied their petition and refused to change the way it made its decisions on greenhouse gas emission targets. The petitioners brought proceedings to judicially review the Department's denial of their petition. In November 2015, the Washington Superior Court recognised that climate change is a threat to the survival of the children and future generations and that it is necessary to reduce the emission of greenhouse gases which contribute to global warming. ${ }^{37}$ The Court reaffirmed that the Washington State Constitution imposes a 'constitutional obligation to protect the public's interest in natural resources held in trust for the common benefit of the people of the State. ${ }^{38}$ The Court rejected the Department's argument that the public trust doctrine was restricted to 'navigable waters' and did not apply to the atmosphere. 'The navigable waters and the atmosphere are intertwined and to argue a separation of the two ... is nonsensical. ${ }^{39}$ The Court recognised a right to the preservation of a healthful and pleasant atmosphere. ${ }^{40}$

Nevertheless, the Court held that the Department was fulfilling its public trust obligations because it was engaging in rulemaking to address greenhouse gas emissions. As the Department had begun considering a cap on emissions, albeit after the suit was brought, the Court could not rule that the Department was failing to fulfil its duty to exercise the statutory authority to establish greenhouse gas emission standards. As its process of rulemaking in this respect was not arbitrary or capricious, it was beyond the Court's judicial review power to assess the merits of the Department's approach. ${ }^{41}$ In particular, the Court

35 Wash Super Ct, 14-2-25295-1-SEA, 19 November 2015, 5.

36 Foster $v$ Washington Department of Ecology (Wash Super Ct, 14-2-25295-1-SEA, 15 September 2015) 10.

$37 \quad$ Ibid 5 .

$38 \quad$ Ibid 8.

39 Ibid.

$40 \quad$ Ibid 9 .

41 Ibid 6, 9-10. 
could not order the Department to use the best science available, as this was a merits consideration outside the scope of the Court's judicial review power. ${ }^{42}$

In February 2016, however, the Department withdrew its proposed rule for mitigating greenhouse gas emissions. The plaintiff relisted the matter before the Court. Given these 'extraordinary circumstances,' the Court vacated parts of its earlier order and ordered the Department to both establish a greenhouse gas emission rule by the end of 2016 and recommend this rule to the legislature in 2017. ${ }^{43}$ The Court noted 'the reason I'm doing this is because this is an urgent situation. This is not a situation that these children can wait on. Polar bears can't wait, the people of Bangladesh can't wait. I don't have jurisdiction over their needs in this matter, but I do have jurisdiction in this court, and for that reason I'm taking this action. ${ }^{44}$ On 1 June 2016, the Department released a draft rule setting limits on greenhouse gas emissions. The applicants argued that the draft rule was contrary to the Court's order because it was based on old emissions data and did not require sufficient greenhouse gas emission reduction. On 15 June 2016, the Department filed a notice of appeal. ${ }^{45}$ On 5 September 2017, the Washington Court of Appeals upheld the Department's appeal. The Court of Appeals held that the Superior Court had abused its discretion in revising its own judgment in granting the applicants' motion for relief from the November 2015 judgment, for three reasons. First, the 'extraordinary circumstance' relied upon to do so, namely the Department's inaction on climate change, was already considered in the original judgment. ${ }^{46}$ Secondly, the Court of Appeals held that the Superior Court had not found any violation by the Department of its statutory obligations to adopt rules establishing air quality standards. ${ }^{47}$ Thirdly, the Superior Court improperly applied the rule that provides the power to revise its previous judgment, as the Court impermissibly granted affirmative relief in addition to the relief in the earlier order, which is not allowed under the rule. ${ }^{48}$

\footnotetext{
$42 \quad$ Ibid 4.

43 Ibid 19; and Foster $v$ Washington Department of Ecology (Wash Super Ct, 14-2-25295-1, 16 May 2016) 2.

44 Fosterv Washington Department of Ecology (Wash Super Ct, 14-2-25295-1, 29 April 2016) 20.

45 Sabin Center for Climate Change Law, 'Washington Department of Ecology Said It Would Appeal Order Requiring Final Greenhouse Gas Rule by End of Year' (Climate Law Update No 89, 16 September 2017) <http://blogs.law.columbia.edu/climatechange/2016/og/16/ updates-to-the-climate-change-litigation-charts-august-and-september-2016/>.

46 Foster $v$ Washington Department of Ecology (Wash Ct Apps, 75374-6-1, 5 September 2017) 13 .

47 Ibid 9.

48 Ibid 15 .
} 
In Funk $v$ Wolf, ${ }^{49}$ the youth plaintiffs challenged the alleged failure of the Commonwealth of Pennsylvania and its various departments and agencies to develop and implement a comprehensive plan to regulate greenhouse gas emissions consistent with its obligations under the Environmental Rights Amendment of the Pennsylvania Constitution (Article 1, Section 27). The plaintiffs alleged that the Commonwealth, as public trustee of Pennsylvania's public natural resources under the Environmental Rights Amendment, had failed in its fiduciary duty to conduct various studies, investigations and other analysis relating to 'how the Commonwealth's obligations as trustee of the public trust are to be fulfilled in "light of climate change and/or increasing concentration of $\mathrm{CO}_{2}$ and GHGs in the atmosphere. ${ }^{.50}$ The plaintiffs also alleged that the Commonwealth had failed to exercise its duty of promulgating regulations or issuing executive orders to limit greenhouse gas emissions in a comprehensive manner. The Pennsylvania Commonwealth Court found that the Environmental Rights Amendment does not disturb the legislative scheme and the actions requested by the plaintiffs had to be required by legislation. The plaintiffs did not identify any legislation or regulation that mandated the Commonwealth of Pennsylvania to perform the specific actions sought in the writ. The Court held that under the existing legislative scheme there was no mandatory duty to conduct the requested studies, promulgate or implement the requested regulation or issue the requested executive orders. Instead, such decisions are either discretionary acts of government officials or a task for Parliament. Accordingly, mandamus did not lie to compel the Commonwealth to make those decisions.

\subsection{Public Trust Litigation in Other Countries}

There has also been some litigation based on the atmospheric public trust in other countries. Several examples are given here.

In Environment People Law $v$ The Cabinet of Ministers of Ukraine, ${ }^{51}$ administrative law proceedings were brought challenging the alleged failure of the Ukrainian government to adequately regulate greenhouse gas emissions. The applicant alleged that the government had failed to uphold its obligation to effectively regulate 'air,' as a natural resource constitutionally recognised as being owned by, and on behalf and for the Ukrainian people. The District Administrative Court of Kyiv partially upheld the applicant's claim by directing

$49144 \mathrm{~A}_{3} \mathrm{~d} 228$ (Penn Comm Ct, 2016).

$50 \quad$ Ibid 237 .

51 District Administrative Court of Kyiv, May $2011<$ https://statici.squarespace.com/ static/571d1ogbo442 6270152febeo/t/576c5b86f5e231d654d321d6/14667191>. 
the government to prepare and release information on its progress in realising Ukraine's Kyoto Protocol obligations. However, the Court declined to grant the other relief sought by the applicant and this was confirmed on appeal.

In Segovia v Climate Change Commission, ${ }^{52}$ in summary, the applicants alleged that the government of the Philippines violated its obligation, as public trustee of the life-source of land, air and water to the people of the Philippines by failing to adequately mitigate climate change and by using [an] immodest amount of fossil fuel. Key issues included whether or not the petitioners had standing and whether a writ of Kalikasan (a remedy available for the violation of the constitutional right to a balanced and healthy ecology, also known as a 'writ of nature') and/or a writ of continuing mandamus (an ongoing order to compel administrative action by government) should be issued. The petition was dismissed. The Supreme Court of the Philippines held the petitioners had standing under the Rules of Procedure for Environmental Cases as citizens and taxpayers, applying Oposa v Factoran. ${ }^{33}$ However, the Court held that the petitioners had failed to demonstrate that the respondents unlawfully refused to implement or had neglected relevant laws and executive or administrative orders. The petitioners also failed to demonstrate that there was a causal link between the alleged unlawful acts or omissions of the government and a violation of the constitutional right to a balanced and healthful ecology of the magnitude required by petitions of this nature.

In Aliv Federation of Pakistan, ${ }^{54}$ amongst other causes of action, the child applicant alleged that the government of Pakistan has, in permitting the development of a particular coalfield and the consequent greenhouse gas emissions, violated the doctrine of public trust. The applicant argued that carbon dioxide pollution 'not only harms and continuously threatens their [Pakistani children's] mental and physical health, quality of life and wellbeing, but also infringes upon their constitutionally guaranteed right to life and the inalienable 'Fundamental Rights' of future generations. Although the Registrar of the Supreme Court of Pakistan initially dismissed the petition, the Supreme Court overturned this decision and the decision on the substantive hearing of the petition is pending.

In Pandey $v$ India, ${ }^{55}$ a nine-year-old applicant petitioned the National Green Tribunal of India to order the Indian government to make directions on

$5^{2} \quad$ GR No. 211010, 7 March 2017, Supreme Court of the Philippines.

53 (1993) 296 Phil 694.

54 Supreme Court of Pakistan, Constitutional petition filed 5 April 2016.

55 National Green Tribunal of India, Original Application No 187 of 2017, Petition filed 25 March 2017. 
climate change. The applicant submitted that 'without action by governments around the world to immediately start reducing carbon dioxide $\left(\mathrm{CO}_{2}\right)$ emissions and other greenhouse gases (GHGs) that cause climate change, in line with achieving global climate stabilisation, children of today and the future will disproportionately suffer the dangers and catastrophic impacts of climate destabilisation and ocean acidification.56 The applicant argued that the Indian government was obliged to take greater action to mitigate the adverse effects of climate change pursuant to the public trust doctrine and India's commitments under the Paris Agreement, and domestic environmental laws and climate change policies. The petition also cited principles of intergenerational equity, the precautionary principle and sustainable development. The applicant argued that while the Indian government had announced several initiatives to combat climate change, no effective action had been taken. The petition has yet to be heard.

\section{Constitutional Environmental Rights}

Climate change litigation has been brought by citizens to remedy infringements of their constitutional rights. The constitutional rights can be fundamental rights, such as the right to life, right to dignity, right to property or right to liberty, or more particular environmental rights such as a right to a clean and healthy environment. Claimants have invoked constitutional rights to remedy governmental action or, more commonly, inaction to mitigate the causes of climate change or to adapt to the consequences of climate change. The cases can be grouped into four categories:

(1) cases seeking to remedy governmental failure to take action to mitigate air pollution, which failure infringes the claimant's right to life or right to a clean and healthy environment;

(2) cases seeking to remedy governmental action that contributes to climate change, which action deprives the claimant of life, liberty or property without due process of law;

(3) cases seeking to remedy governmental action to approve development that will contribute to climate change, which will infringe the claimant's right to a clean and healthy environment; and

$5^{6} \quad$ Pandey $v$ India (National Green Tribunal of India, Original Application No 187 of 2017, Petition filed 25 March 2017) 2-3. 
(4) cases seeking to remedy governmental failure to take action to adapt to the consequences of climate change, which failure infringes the claimant's fundamental rights.

\subsection{Right to Life Affected by Governmental Failure to Mitigate Air Pollution}

Early litigation in the South Asia region, based on infringement of fundamental rights, concerned air pollution. Claimants argued that governmental inaction to mitigate chronic air pollution, particularly vehicular air pollution, that severely affected people's health and life, infringed the claimants' right to life. This rights-based air pollution litigation paved the way for the more recent climate change litigation invoking fundamental rights. Strong parallels can be drawn between the approaches taken by courts in adjudicating constitutional rights-based air pollution litigation and the role of courts in adjudicating climate change litigation. In particular, the history of court orders directing governments to implement air pollution mitigation measures may foreshadow similar court orders in climate change litigation. Additionally, court orders to mitigate air pollution have ancillary benefits for climate change mitigation: the action taken to reduce other air pollutants may also reduce greenhouse gases. It is instructive, therefore, to consider air pollution litigation over the past couple of decades based on violation of constitutional rights in Bangladesh, Nepal, Nigeria, Pakistan and India.

In Farooque $v$ Government of Bangladesh, ${ }^{57}$ a public interest lawyer claimed that, while the Bangladesh government had legislated to regulate industrial air pollution, there was no evidence to show 'any' effective implementation of the legislation. The failure of the government to implement the law contravened the constitutional right to a 'qualitative life among others, free from environment hazards. ${ }^{58}$ Consequently, the Bangladesh Supreme Court ordered the government to 'adopt adequate and sufficient measures to control pollution. ${ }^{59}$ In a subsequent case, Farooquev Government of Bangladesh, ${ }^{60}$ the same petitioner challenged the failure of government to adequately regulate vehicle-generated air pollution. While the government had both legislated and taken some policy action to control vehicular air pollution, the petitioner submitted that the government had failed to safeguard the 'fundamental rights

57 Supreme Court of Bangladesh, WP No 891 of 1994, 15 July 2001.

58 Ibid 17.

59 Ibid 19.

$60 \quad$ (2002) 22 BLD (HCD) 345 (Supreme Court of Bangladesh). 
guaranteed under the Constitution' 61 of citizens by allowing vehicular pollution to pose a 'deadly threat ... to city dwellers.' ${ }^{2}$ The Supreme Court ordered the government to undertake 'urgent preventative measures' to control the 'emission of hazardous black smoke' including phasing out ' 2 stroke 3 wheelers' and enforcing international petroleum standards. ${ }^{63}$

In Prakash Mani Sharma $v$ HMG Cabinet Secretariat, ${ }^{64}$ the Supreme Court of Nepal held that the Nepal government had a constitutional public health obligation to reduce vehicular air pollution. To remedy the inadequate implementation of air pollution reduction measures, the Court ordered the government to enforce essential measures within two years for the protection of public health from smoke emitting from buses, minibuses, tractors and trucks, including small tempos and taxis, in the Kathmandu Valley. In a later case brought by the same petitioner, Prakash Mani Sharma $v$ HMG Cabinet Secretariat, the Supreme Court of Nepal held that the government's constitutional obligations to 'protect the health of the people' 65 and work towards 'a pollution-free environment' 66 required the government to address brick kilngenerated air pollution. Thus, the Court directed the government to close brick kilns proximate to tourist areas and schools and ensure the installation of pollution-controlling devices in kilns elsewhere.

In Gbemre $v$ Shell Petroleum Development Company Nigeria Limited, ${ }^{67}$ the Nigerian Federal High Court ordered Shell to cease polluting by way of gas flaring on the basis that this gas flaring contravened the constitutional right to a 'clean, poison-free, pollution-free healthy environment.'

In Mansoor Ali Shah $v$ Government of Punjab, ${ }^{68}$ the parties agreed that the constitutional right to life required the Punjab government to protect citizens in Lahore from vehicular air pollution. The Punjab government submitted that it was, however, 'making all efforts to cure air pollution.' ${ }^{69}$ In earlier proceedings, the Lahore High Court had ordered the establishment of the Lahore Clean Air Commission to report on how to address vehicular pollution. The parties consented to the Court directing the government to implement a suite of air pollution reduction measures recommended by the commission, including the

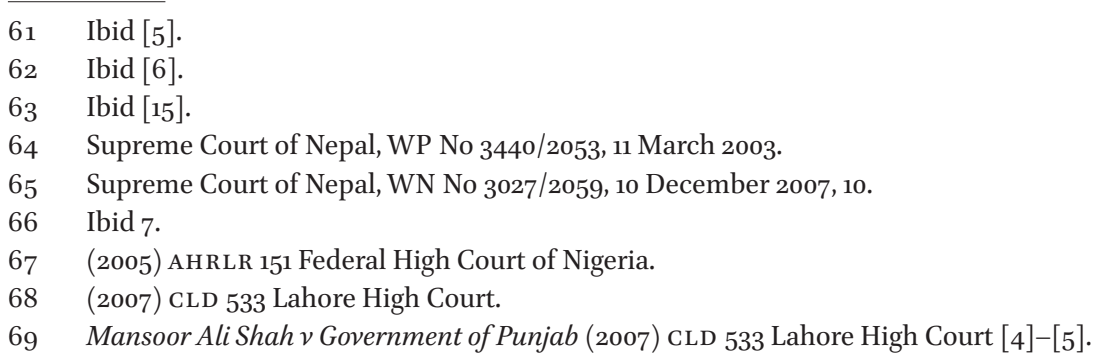


phasing out of dirty buses and existing two-stroke rickshaws (auto and motorcycle), the creation of bus lanes, the enforcement of the ban on registering motorcycle rickshaws and the establishment of air quality and fuel standards.

In Smoke Affected Residents Forum v Municipal Corporation of Greater Mumbai, 70 in order to safeguard the constitutional right to health of the residents of Mumbai, the Bombay High Court ordered the City of Mumbai to implement air pollution mitigation measures 'to protect future generations,' including phasing out, or converting, a particular taxi model and old threewheeler vehicles.

In Vardhaman Kaushik $v$ Union of India ${ }^{71}$ the National Green Tribunal of India made many orders directing the Indian government to take particular actions to address air pollution. In subsequent orders made in 2016, in ongoing related litigation, concerning unprecedented levels of air pollution in Delhi and surrounding areas, the National Green Tribunal observed that the level of air pollution '[v]iewed from any rational angle ... is disastrous. ${ }^{72}$ To ensure the proper implementation of previous air pollution orders in these and related proceedings, the Tribunal ordered the constitution of a centralised committee (consisting of various departmental secretaries) and state level committees. The Tribunal charged these committees with preparing a 'complete action plan for environmental emergency as well as prevention and control of air pollution' to implement previous air pollution judgments and orders of the Court. ${ }^{73}$ Moreover, the Tribunal ordered that if air pollution reaches a certain 'environmental emergency threshold,' the government must take seven emergency measures, including the measure of stopping all 'construction, demolition activities and transportation of construction material.'

In Court (on its own motion) $v$ State of Himachal Pradesh ${ }^{74}$ the National Green Tribunal made a series of orders directing the State government to take action to redress the environmental degradation of the 'Crown Jewel' of Himachal Pradesh - the eco-sensitive Rohtang Pass—caused by inadequately regulated tourism-related development and activities, including vehicular air pollution. Of the various tourism-related impacts, the Tribunal noted that Black Carbon (primarily unburnt fuel, including from vehicular pollution) has been 'the major causative factor for rapid melting of glacier[s] in the

\footnotetext{
702003 (1) Bom CR 450 (Bombay High Court), in particular at [6]-[7].

71 National Green Tribunal of India, Original Application No 21 of 2014, 4 December 2014.

72 Vardhaman Kaushik $v$ Union of India (Order of the National Green Tribunal regarding deteriorating air quality in Delhi, Original Application Nos 21/2014, 95/2014, 303/2015, 181 /2013 and 609 /2016, 10/11/2016) 9 .

73 Ibid 10, 15-17.

74 National Green Tribunal of India, Application No 237 (ТнС)/ 2013.
} 
north-western Himalaya' and a significant contributor to global warming. On 6 February 2014, the Tribunal, after articulating the importance of the constitutional right to a clean environment, ordered the government to take various actions to reduce vehicular pollution, such as enforcing emissions standards for vehicles and phasing out vehicles more than ten years old. On 9 May 2016, the Tribunal directed the government to submit to the Tribunal a comprehensive status/compliance report relating to the various environmental orders of the Tribunal. ${ }^{75}$

In MC Mehta $v$ Union of India, ${ }^{76}$ there is a 30-year history of court orders compelling Indian governments to take air pollution mitigation measures to protect constitutional rights, including a right to a clean and healthy environment. For example, the Supreme Court of India ordered on 5 April 2002 that diesel buses in Delhi be converted from diesel to cleaner natural gas. ${ }^{77}$ On 16 December 2015, the Supreme Court made further orders including, for example, the prohibition of the registration of 'luxury' diesel cars and suvs (with a diesel capacity of 2000 cubic centimetres and above) in Delhi and requiring the imposition of green taxes/toll-based measures to stop diesel trucks entering, rather than bypassing, Delhi. ${ }^{78}$ On 5 January 2016, the Supreme Court ordered that all taxis operating in the National Capital Region be converted to natural gas. ${ }^{79}$ On 10 May 2016, the Court prohibited the registration of diesel city taxis. ${ }^{80}$ On 12 August 2016, the Court lifted the prohibition it had ordered on 16 December 2015 on the registration of certain diesel cars on the condition that an 'environment protection charge' (of $1 \%$ of the ex-showroom price of diesel vehicles, with capacity of 2000 cubic centimetres or greater, sold in Delhi) is levied on the registration of such cars. ${ }^{81}$

\subsection{Fundamental Rights Affected by Governmental Failure to Adapt to Climate Change}

A recent case in Pakistan, Asghar Leghariv Federation of Pakistan, ${ }^{82}$ built upon the air pollution litigation for contravention of environmental rights. Pakistan

75 Court (on its own motion) $v$ State of Himachal Pradesh (National Green Tribunal of India, Original Application No 237 of 2013, 9 May 2016).

$76 \quad 1987$ SCR (1) 819 .

77 MC Mehta $v$ Union of India 2002 (2) SCR 963.

78 MC Mehta $v$ Union of India (Writ Petitions No 817 of 2015, 116 of 2013 and 728 of 2015, 16 December 2015).

79 MC Mehta v Union of India (2016) 4 SCC 269.

8o MC Mehtav Union of India (Writ Petition No 13029/1985, 10 May 2016).

81 MC Mehta $v$ Union of India (Writ Petition No 13029/1985, 12 August 2016).

82 Lahore High Court, WP No 25501/2015, 4 September 2015; Asghar Leghariv Federation of Pakistan (Lahore High Court, WP No 25501/2015, 14 September 2015). 
had adopted two climate-related policies, the National Climate Change Policy 2012 and the Framework for Implementation of Climate Change Policy (20142030), which identified actions the government should take to adapt to the consequences of climate change, such as droughts. However, the Pakistan government had not implemented those policies. The petitioner, whose family of farmers were suffering from the prolonged drought, brought proceedings in the Lahore High Court claiming that the government's inaction in implementing the policies to address the consequences of climate change offended his fundamental rights (the right to life, including the right to a healthy and clean environment, the right to human dignity, the right to property and the right to information), which are to be read with the constitutional principles of democracy, equality, social, economic and political justice, and the international environmental principles of sustainable development, the precautionary principle, environmental impact assessment, inter- and intra-generational equity and the public trust doctrine.

The Lahore High Court upheld the petitioner's claim that the government's inaction in implementing the Policy and the Framework offended his fundamental human rights. By way of remedy, the Court ordered on 14 September 2015 the establishment of a Climate Change Commission to effectively implement the Policy and the Framework. Accordingly, the Court assigned 21 members to the Commission from various government Ministries and Departments and ordered that it file interim reports as and when directed by the Court. The Court said that: 'For Pakistan, climate change is no longer a distant threat - we are already feeling and experiencing its impacts across the country and the region.' The Climate Change Commission submitted to the Court a report dated 16 January 2016, which included 14 findings and 16 major recommendations. In the orders of 18 January 2016, the Court commended the work of the Commission; observed that through the Commission's process of examining and reporting on the Policy and the Framework, 'modest progress' had been made in achieving their objectives and goals; ${ }^{83}$ ordered that the 'priority items under the Framework' be achieved by the Punjab government by June 2016; ${ }^{84}$ tasked the Commission with investigating further achievable 'short term actions' under the Framework; ${ }^{85}$ directed the Punjab government to seriously investigate the funding requirements of climate change action and

\footnotetext{
83 Asghar Leghariv Federation of Pakistan (Lahore High Court, WP No 25501/2015, 18 January 2016) [3].

84 Ibid [4].

85 Ibid [4].
} 
'allocate a budget for climate change in consultation with' the Commission; ${ }^{86}$ and directed the relevant media regulatory authority to consider 'granting more prime time for the awareness and sensitisation on the issue of climate change. 87

The Commission submitted a supplemental report on 24 February 2017, recommending various actions, including priority actions, and a further supplemental report on 24 January 2018 on the implementation of priority actions. The Commission submitted that $66 \%$ of the priority items of the Framework had been completed due to the effort made by the Commission. ${ }^{88}$ The Commission recommended that, in this circumstance, responsibility for implementing the balance of the Framework could be left to the government. On 25 January 2018, the Lahore High Court agreed and dissolved the Climate Change Commission and instead constituted a Standing Committee on Climate Change to assist and ensure the continued implementation of the Policy and Framework. ${ }^{89}$

\section{3 'Due Process' Rights Affected by Governmental Action Contributing to Climate Change}

In the United States, there is a particular constitutional right in Federal and State constitutions that a person is not to be deprived of life, liberty or property without due process of law (the due process clause). Claimants have invoked the due process clause in climate change litigation.

In Juliana $v$ USA, the atmospheric public trust litigation referred to earlier, the plaintiffs also sought declaratory relief that governmental action to approve fossil fuel development is resulting in catastrophic climate change and violating the plaintiffs' constitutional rights to life and equal protection and the implicit constitutional right to a stable climate. The plaintiffs challenged affirmative governmental action, such as leasing land and issuing permits allowing fossil fuel development, under the due process clause of the Fifth Amendment to the US Constitution, which bars the Federal government from depriving a person of 'life, liberty or property' without 'due process' of law. As stated earlier, on 10 November 2016 the US District Court for the District of Oregon declined to grant the defendants' motion to dismiss the proceedings. ${ }^{90}$ The Court noted that the applicable level of judicial scrutiny

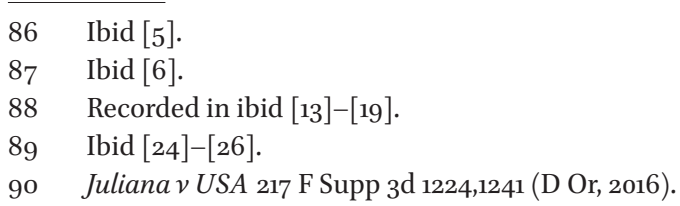


of affirmative governmental action under the due process clause depends on the right affected. 'The default level of scrutiny is rational basis, which requires a reviewing court to uphold the challenged governmental action so long as it "implements a rational basis of achieving a legitimate governmental end."'91 Where, however, the government infringes a 'fundamental right,' a reviewing court applies strict scrutiny. 'Substantive due process forbids the government to infringe certain "fundamental" liberty interests at all, no matter what process is provided, unless the infringement is narrowly tailored to serve a compelling state interest.92 The parties noted, and the Court agreed, that the government's affirmative actions would survive rational basis review. The plaintiffs' case therefore depended on whether the government's actions infringed a fundamental right. The Court noted that: '[f]undamental liberty rights include both rights enumerated elsewhere in the Constitution and rights and liberties which are either (i) 'deeply rooted in this Nation's history and tradition;' or (2) 'fundamental to our scheme of ordered liberty.' ${ }^{3}$

The Court found that ' $[\mathrm{t}]$ he right to a climate system capable of sustaining human life is fundamental to a free and ordered society. Just as marriage is the "foundation of the family," a stable climate system is quite literally the foundation "of society, without which there would be neither civilization nor progress." 94 Such a stable climate system is a necessary condition to exercising other rights to life, liberty and property. ${ }^{95}$ The Court was cautious in how it framed the fundamental right. It was not a right to freedom from any pollution or any climate change. Rather, it is a right to a climate system capable of sustaining human life. The Court stated:

In framing the fundamental right at issue as the right to a climate system capable of sustaining human life, I intend to strike a balance and to provide some protection against the constitutionalization of all environmental claims. On the one hand, the phrase 'capable of sustaining human life' should not be read to require a plaintiff to allege that governmental action will result in the extinction of humans as a species. On the other hand, acknowledgment of this fundamental right does not transform any minor or even moderate act that contributes to the warming

\footnotetext{
$91 \quad$ Ibid 1248.

92 Ibid 1248-1259 (emphasis in the original), applying Reno v Flores 507 US 292, 302 (1993).

93 Juliana v USA 217 F Supp 3d 1224, 1249 (D Or, 2016).

94 Ibid 1250, citing amongst others Minors Oposa $v$ Secretary of the Department of Environment and Natural Resources 22 ILM 173, 187-188.

95 Juliana v USA 217 F Supp 3d 1224, 1250, quoting Maynardv. Hill 125 US 190, 211 (1888) (D Or, 2016).
} 
of the planet into a constitutional violation. In this opinion, this Court simply holds that where a complaint alleges governmental action is affirmatively and substantially damaging the climate system in a way that will cause human deaths, shorten human lifespans, result in widespread damage to property, threaten human food sources, and dramatically alter the planet's ecosystem, it states a claim for a due process violation, To hold otherwise would be to say that the Constitution affords no protection against a government's knowing decision to poison the air its citizens breathe or the water its citizens drink. Plaintiffs have adequately alleged infringement of a fundamental right. ${ }^{96}$

As noted earlier, the Ninth Circuit Court of Appeals and the US Supreme Court have so far dismissed further applications to stay the proceedings; $;{ }^{97}$ and the setting of the trial date is awaited. ${ }^{98}$

Another climate change case invoking the due process clause is $R e$ Application of Maui Electric Company. ${ }^{99}$ The Sierra Club challenged the Hawai'i Public Utilities Commission's decision to deny the environmental nongovernmental organisation the right to participate in proceedings before the Commission on an application for a power purchase agreement between an electric utility company and an energy producer. The energy producer relied on the burning of coal and petroleum in its operations and had been charged with violations of the State's visible emissions standards. ${ }^{100}$ Article XI, Section 9 of the Hawai'i Constitution guarantees 'the right to a clean and healthful environment, as defined by laws relating to environmental quality.' Article I, Section 5 of the Hawai'i Constitution states '[n]o person shall be deprived of life, liberty or property without due process of law.' The Sierra Club submitted that under Article XI, Section 9 of the Constitution it had a protectable property interest in a clean and healthful environment, that the Commission's decision to approve the power purchase agreement affected this property interest and that, in accordance with Article I, Section 5 of the Constitution, it should have been afforded a due process hearing due to the risk of deprivation of this property interest. ${ }^{101}$ The Intermediate Court of Appeals dismissed Sierra

\footnotetext{
$96 \quad$ Ibid.

97 USA v US District Court for District of Oregon (9th Cir, 18-71928, 16 July 2018); USA v US District Court for District of Oregon (9th Cir, 18-71928, 20 July 2018); USA v US District Court for District of Oregon (US Supreme Court, 18A65, 30 July 2018).

98 Julianav USA (D Or, 6:15-cv-1517-AA, 24 October 2018.

$99408 \mathrm{P}_{3} \mathrm{~d}_{1}$ (Haw Sup Ct, 2017).

100 Re Application of Maui Electric Company 408 P 3d 1, 17 (Haw Sup Ct, 2017).

101 Ibid 5.
} 
Club's petition for lack of jurisdiction. However, on appeal, the Supreme Court of Hawai'i (with two judges dissenting) determined to grant to the petitioners a writ of certiorari (an order for the review of the earlier judicial decision), remanding the case to the Intermediate Court for further proceedings.

The Supreme Court of Hawai'i held that a protectable property interest, under the due process clause, is simply 'a benefit to which the claimant is legitimately entitled,' 102 or 'a benefit - tangible or otherwise - to which a party has "a legitimate claim of entitlement."'103 The Court held that the right to a clean and healthful environment relied on by the Sierra Club is a substantive right guaranteed by Article XI, Section 9 of the Constitution. Article XI, Section 9 is 'is self-executing, and it establishes the right to a clean and healthful environment 'as defined by laws relating to environmental quality.'104 The Court held ' $[t]$ his substantive right is a legitimate entitlement stemming from and shaped by independent sources of state law, and is thus a property interest protected by due process.'105 The Court noted that the substantive right under Article XI, Section 9 'is defined by existing laws relating to environmental quality.' The Court considered that Chapter 269 of the Hawai'i Revised Statutes (HRS), which includes the duties and operations of the Commission in regulating public utilities, is a law relating to environmental quality within the meaning of Article XI, Section 9. The Court observed that HRS § 269-6b makes it mandatory for the Commission, when exercising its duties, to recognise the need to reduce reliance on fossil fuels and explicitly consider the levels and effect of greenhouse gas emissions. HRS § 269-27.2 concerns the utilisation of electricity generated from non-fossil fuels and Part $\mathrm{v}$ prescribes renewable portfolio standards. The Court found that " $[\mathrm{t}]$ hese regulations would appear to be precisely the type of "laws relating to environmental quality" that article XI, section 9 references. ${ }^{\prime 106}$ The Court held: 'We therefore conclude that HRS Chapter 269 is a law relating to environmental quality that defines the right to a clean and healthful environment under article XI, section 9 by providing that express consideration be given to reduction of greenhouse gas emissions in the decision-making of the Commission. Accordingly, we hold that Sierra Club has

\footnotetext{
102 Ibid 12, applying Pele Def Fund v Puna Geothermal Venture 881 P 2d 1210, 1214 (1994).

103 Re Application of Maui Electric Company 408 P 3d 1, 12 (Haw Sup Ct, 2017), applying Board of Regents of State Colleges v Roth 408 US 564, 577 and Sandy Beach Def. Fund v City Council of Honolulu 773 P 2d 250, 260 (1989).

104 Re Application of Maui Electric Company $408 \mathrm{P}_{3} \mathrm{~d}$ 1, 13 (Haw Sup Ct, 2017), applying City of Hawai'iv Ala Loop Homeowners 235 P $3 \mathrm{~d} 1103,1127$ (2010).

105 Re Application of Maui Electric Company 408 P 3 d 1, 13 (Haw Sup Ct, 2017).

106 Ibid $14-15$.
} 
established a legitimate claim of entitlement to a clean and healthful environment under article XI, section 9 and HRS Chapter 269.107

The Supreme Court then considered what procedures due process required the Commission to follow in determining whether to approve the power purchase agreement. The Court found the Commission's approval of the power purchase agreement would adversely affect the Sierra Club member's interest in a clean and healthful environment as defined by HRS Chapter $269 .{ }^{108}$ The Court disagreed that only those members adjacent to the fossil fuel plant would be able to demonstrate a protectable property interest: 'those who are adversely affected by greenhouse gas emissions produced by the burning of fossil fuels may not necessarily be limited to those who live in the areas immediately adjacent to the source of the emissions. ${ }^{.109}$ Accordingly, the Commission should have afforded the Sierra Club the opportunity to participate by way of a contested case hearing by the Commission to consider the impacts of approving the power purchase agreement on the Sierra Club member's right to a clean and healthful environment. ${ }^{110}$

\subsection{Right to a Quality Environment Affected by Governmental Action Contributing to Climate Change}

Litigation has been brought challenging governmental decisions to approve activities that contribute to climate change, such as activities that directly or indirectly result in the emission of greenhouse gases or the clearing of forests that act as sinks that sequester carbon.

In Greenpeace v Norwegian Ministry of Petroleum and Energy, ${ }^{111}$ Greenpeace and Nature and Youth brought proceedings against the Norwegian government seeking review of the government's decision to grant oil drilling licences in the Arctic. The activities of oil drilling, and transportation and combustion of the oil extracted, emit greenhouse gases and contribute to climate change. The applicants argued that the grant of drilling licences was contrary to the government's obligations under the Paris Agreement and the right to a healthy and safe environment for future generations granted by the Norwegian Constitution. The Oslo District Court found that the right to a healthy environment is protected by the Norwegian Constitution, and that the government must protect that right. However, the Court found that the government had not breached

\footnotetext{
$\overline{107 \quad \text { Ibid } 16 .}$

108 Ibid 18.

109 Ibid 20.

110 Ibid 21.

111 Oslo District Court, No. 16-166674TVI-OTIR/o6, 4 January 2018.
} 
the Constitution in granting the licences because it had fulfilled the necessary duties required before making its decision. ${ }^{12}$ Greenpeace announced on 5 February 2018 that it was appealing the decision to the Supreme Court. ${ }^{113}$

In Friends of the Irish Environment CLG v Fingal County Council, ${ }^{114}$ an environmental non-governmental organisation challenged the Fingal County Council's decision to approve a five-year extension to the planning permission it had granted to the Dublin Airport Authority to construct a new runway. The plaintiff argued that the construction and use of the new runway would cause an increase in greenhouse gas emissions and hasten climate change. The High Court found that the plaintiff lacked standing to participate in the extension decision in order to bring the claim. However, the Court recognised the 'personal constitutional right to an environment' under the Irish Constitution: 'A right to an environment that is consistent with the human dignity and wellbeing of citizens at large is an essential condition for the fulfilment of all human rights. It is an indispensable existential right that is enjoyed universally, yet which is vested personally as a right that presents and can be seen always to have presented, and to enjoy protection, under Article 40.3.1 of the Constitution. It is not so Utopian a right that it can never be enforced. Once concretised into specific duties and obligations, its enforcement is entirely practicable.'115 The Court went on to say that although concrete duties and responsibilities were yet to be defined, the recognition of the right, as in this case, was the first step in its enforcement. Nevertheless, the Court found that the County Council did not breach the right to an environment by extending the planning permission.

In Salas, Dino and others $v$ Salta Province, ${ }^{116}$ indigenous communities in Argentina challenged, by means of a writ of amparo (a remedy for the protection of constitutional rights), the issuing of logging permits for native forests on

112 A summary of the judgment in English is available at Sabin Center for Climate Change Law, 'Greenpeace Nordic Ass'n and Nature and Youth v. Ministry of Petroleum and Energy' (Climate Change Litigation Database, 2018) <http://climatecasechart.com/ non-us-case/greenpeace-nordic-assn-and-nature-youth-v-norway-ministry-of-petro leum-and-energy/>.

113 Greenpeace, 'Greenpeace and Nature and Youth take the Norwegian Government to the Supreme Court' (Press Release, 5 February 2018) <https://www.greenpeace.org/ international/press/14527/greenpeace-and-nature-and-youth-take-the-norwegian-gov ernment-to-the-supreme-court/>.

114 High Court of Ireland, No 344 JR, 21 November 2017 <http://www.friendsoftheirishenvi ronment.org/images/Climate/Airport_judgment_Barret__21.11.17.pdf>.

115 Friends of the Irish Environment CLG v Fingal County Council (High Court of Ireland, No 344 JR, 21 November 2017) [264].

$116 \operatorname{CSJN}$ (Arg), S1144.XLIV, 26 March 2009. 
the basis that the decision to issue these permits contravened constitutional rights, including the right to a healthy and balanced environment (Article 41). In upholding the amparo action, the Argentinian Supreme Court of Justice held, inter alia, that the clearing of one million hectares of forest posed a threat of serious damage 'because it may substantially change the climate of the entire region, thus affecting not only current inhabitants, but also future generations.'

On 29 January 2018, a group of 25 plaintiffs, between 7 and 26 years old, filed a tutela, a special action under the Colombian Constitution used to protect fundamental rights, before the Superior Tribunal of Bogota. ${ }^{117}$ The plaintiffs come from 17 cities and municipalities in Colombia, all of which are significantly threatened by climate-related impacts. The plaintiffs demanded that the relevant Colombian Ministries and Agencies protect their rights to a healthy environment, life, food and water. They claimed that rampant deforestation in the Colombian Amazon and climate change are threatening these rights. They sought orders that the government halt deforestation in the Colombian Amazon. The Colombian Amazon is the region with the highest deforestation rate in the country, which contributes to climate change by releasing carbon dioxide into the atmosphere. In 2016, deforestation in Colombia increased by $44 \%, 39 \%$ of which was concentrated in the Amazon. The plaintiffs argued that all ecosystems are connected. For example, the Amazonian rainforest directly relates to the drinking water enjoyed by the 8 million inhabitants of Bogota because rainfall from the Amazon feeds the páramo, an alpine tundra ecosystem that provides most of Colombia's drinking water. The plaintiffs claimed that deforestation is threatening the fundamental human rights of the plaintiffs who are young today and who will face the impacts of climate change for the rest of their lives. ${ }^{118}$

On 12 February 2018, the Tribunal denied the plaintiffs' claim. ${ }^{119}$ The plaintiffs appealed this decision to the Supreme Court of Justice which, on 5 April 2018, upheld the appeal. ${ }^{120}$ The Supreme Court held that deforestation in the Amazon poses an 'imminent and serious' threat to current and future generations due to its impact on climate change. ${ }^{121}$ The Court found that this

\footnotetext{
117 Future Generations $v$ Ministry of the Environment and others (Colom Sup Ct, 11001-22-03ooo-2018-00319-01, 5 April 2018).

118 Dejusticia, 'Colombian Youth File the First Climate Change lawsuit in Latin America' (29 January 2018) <https://www.dejusticia.org/en/colombian-youth-file-first-climatechange-lawsuit-latin-america/>.

119 Ibid.

120 Future Generations $v$ Ministry of the Environment and others (Colom Sup Ct, 11001-22-03000-2018-00319-01, 5 April 2018).

121 Ibid 34
} 
impact attacks the plaintiffs' fundamental rights to life, water, clean air and a healthy environment as well as the human rights of future generations. The Court found that the Amazon is an entity 'subject of rights' and that the Colombian government has a duty of 'protection, conservation, maintenance and restoration' of the Amazon. ${ }^{122}$ The Court made orders across three levels of government. The Court ordered the Federal government to propose a plan to reduce deforestation in the Colombian Amazon and to establish an 'intergenerational pact for the life of the Colombian Amazon' with the plaintiffs, scientists and community members with the aim of reaching zero deforestation. ${ }^{123}$ The Court ordered municipal governments to update their Land Management Plans and to propose a plan for reaching zero deforestation. The Court also ordered regional environmental authorities to put forward a plan for reducing deforestation.

\section{Human Rights}

\section{1}

\section{Litigation under European Convention for Protection of Human Rights}

Human rights under international conventions and instruments may provide a source for climate change litigation. To date, litigation under the European Convention for the Protection of Human Rights and Fundamental Freedoms has not focused expressly on the impact of climate change on human rights, but rather more generally on the environmental impact of projects and activities on human rights. The European Court for Human Rights (ECtHR) has upheld rights under the European Convention for the Protection of Human Rights and Fundamental Freedoms including the right to life, the right to a fair trial and the right to respect for family and private life. Four cases before the European Court of Human Rights concern the infringement of human rights by air pollution. These cases give some indication of the direction in which the Court will move if and when a substantive climate change case is submitted to it.

In Fadeyeva $v$ Russia, ${ }^{124}$ the applicant alleged that the operation of a steel plant (the largest iron smelter in Russia) in close proximity to her home endangered her health and wellbeing due to the State's failure to protect her private life and home from severe environmental nuisance from the plant, in violation

\footnotetext{
122 Ibid 45 .

123 Ibid 45 .

124 [2005] ECHR 376 (2007) 45 EHRR 10.
} 
of Article 8 of the Convention. The ECtHR held that while the Convention does not contain a right to nature preservation as such, Article 8 could apply if the adverse effects of the environmental pollution had reached a certain minimum level. This threshold had been reached, as the average pollution levels far exceeded the safe concentrations of toxic elements and local courts had recognised the applicant's right to resettle. ${ }^{125}$ The ECtHR held Russia to be in breach of Article 8 and awarded damages and costs. ${ }^{126}$ The Court also ordered the Russian government to 'take appropriate measures to remedy' her situation. The Court observed that it was not its role to 'dictate precise measures which should be adopted by States in order to comply' with their human rights obligations. Nevertheless, in 2007, the ECtHR Department for Execution of Judgments found that Russia had not provided evidence that any appropriate measures had been taken, despite Russia's claims to that effect. ${ }^{127}$

In Okyay $v$ Turkey, ${ }^{128}$ the applicants sought to stop the operation of three thermal power plants situated in the Aegean region of Turkey. The plants used low quality lignite coal. Sulphur and nitrogen emissions from the sites affected the air quality of a large area, while activities incidental to the plant's operation adversely affected the region's biodiversity. The applicants brought proceedings in local courts seeking to stop the operation of the plants, arguing that the plants did not have the required licences to function lawfully. They relied on the right to a healthy, balanced environment in Article 56 of the Turkish Constitution, as well as provisions of the Environment Act requiring authorities to prevent pollution or ensure its effects are mitigated. The local courts upheld their appeal, finding that the plants did not have the required licences and ordered the plants to stop operating. The Turkish authorities refused to enforce the local courts' decisions. The applicants complained to the ECtHR that their right to a fair hearing under Article 6 of the Convention had been breached by the authorities' failure to enforce the local courts' decisions to halt the operation of the power plants. The ECtHR found Turkey had violated Article 6 and awarded the applicants compensation. ${ }^{129}$

Giacomelliv Italy ${ }^{130}$ involved a complaint about noise and emissions from a waste treatment plant that processed hazardous waste. The applicant, who lived 30 metres from the plant, sought damages and to have the facility closed

\footnotetext{
125 Ibid [8o], [84], [86].

126 Ibid [134], [138], [149]-[150].

127 Business \& Human Rights Resource Centre, 'Fadeyeva v Russia’ <https://www.businesshumanrights.org/en/fadeyeva-v-russia-re-severstal-smelter>.

128 Application No 36220/97, ECHR 2005-VII.

129 Ibid [74]-[75], [79].

130 Application No 59909/oo, ECHR 2006-XII.
} 
down. She complained that the persistent noise and harmful emissions from the plant constituted a severe disturbance of her environment and a permanent risk to her health and home in breach of Article 8 (Right to respect for private and family life) of the Convention. ${ }^{131}$ The company operating the plant had been granted an operating licence in 1982 to treat non-hazardous waste and then a further authorisation in 1989 to treat harmful and toxic waste. Neither of these decisions was preceded by appropriate environmental investigation and the company was not required to carry out an environmental impact assessment until 1996. On two occasions the Ministry of the Environment found that the plant's operations were incompatible with environmental regulations. In addition, a Regional Administrative Court had held that the plant's operation had no legal basis and should be suspended immediately. However, the administrative authorities did not at any time order the closure of the facility. ${ }^{132}$ The ECtHR held that Article 8 may apply in environmental cases whether the pollution is directly caused by the State or whether State responsibility arises from the failure to properly regulate private-sector activities. The Court must ensure that a fair balance is struck between the interests of the community and the individual's right to respect of the home and private life. ${ }^{133}$ The ECtHR held that this individual right is not confined to concrete or physical breaches, such as unauthorised entry into a person's home, but also those that are not concrete or physical, such as noise, emissions, smells or other forms of interference. ${ }^{134}$ After considering the actions of the administrative authorities, the ECtHR concluded that the State did not succeed in striking a fair balance between the interest of the community in having a plant for the treatment of toxic industrial waste and the applicant's effective enjoyment of her right to respect for her home and private and family life. ${ }^{135}$ The ECtHR therefore found a violation of Article 8 .

In another air pollution case, MFHR $v$ Greece, ${ }^{136}$ the European Commission of Social Rights held that the Greek government had violated Article 11 of the European Social Charter - the right to protection of health - in failing 'to strike a reasonable balance between the interest of persons living in the lignite mining areas and the general interest' in managing and regulating air pollution from lignite mining operations. ${ }^{137}$

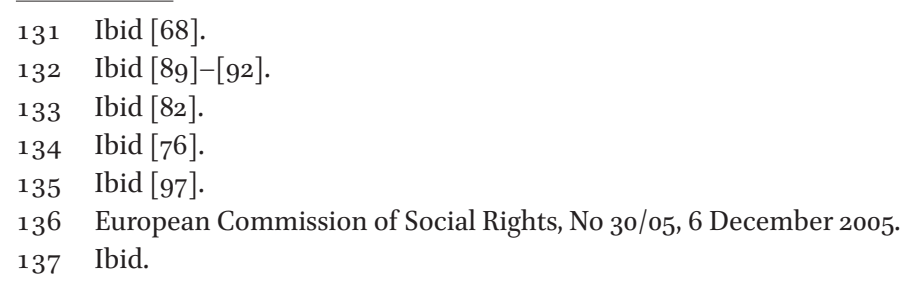




\subsection{Litigation under American Convention on Human Rights}

Litigation under the American Convention on Human Rights has directly raised the impact of climate change on human rights. In 2005, the Inuit, indigenous people in the Arctic region filed a petition against the United States alleging human rights violations resulting from the United States' failure to limit its emissions of greenhouse gases and therefore reduce the impact of climate change. The petitioners invoked the right to culture, the right to property, and the right to the preservation of health, life and physical integrity. The InterAmerican Commission for Human Rights rejected the petition in 2006 without giving reasons. However, on the request of the petitioners, the Commission agreed to afford the petitioners a hearing of the matter in 2007 but no further judgment was subsequently given. ${ }^{138}$

In 2016, the Colombian government requested the Inter-American Court of Human Rights to issue an opinion on State obligations to the environment arising under Article 1(1) (Obligation to Respect Rights), Article 4(1) (Right to Life) and Article 5(1) (Right to Humane Treatment) of the American Convention of Human Rights, including the obligation of State Parties to prevent environmental harm occurring outside their territory. ${ }^{139}$ Of particular concern was the transboundary environmental impact of proposed major infrastructure projects in the Caribbean, such as the proposed Nicaraguan canal. In February 2018, the Court published its opinion of 15 November 2017..$^{140}$ The Court found that there is an 'irrefutable relationship' between the protection of the environment and human rights because environmental degradation and climate change affect the enjoyment of human rights. ${ }^{141}$ The Court found that Article 1 of the Convention obliges State Parties to prevent human rights violations of persons within their territory and outside their territory, where these persons are within the State's 'effective authority or control.'142 This obligation

138 Earthjustice, 'Nobel Prize Nominee Testifies about Global Warming' (1 March 2007) $<$ http://www.earthjustice.org/news/press/o07/nobel-prize-nominee-testifies-aboutglobal-warming.html>; H Osofsky, 'Inuit Petition as a Bridge? Beyond Dialectics of Climate Change and Indigenous Peoples' Rights' (2007) 31 American Indian Law Review 675 .

139 Republic of Colombia, Request for Advisory Opinion of the Inter-American Court of Human Rights (14 March 2016).

140 Inter-American Court of Human Rights (Advisory Opinion OC-23/17 of 15 November 2017).

141 Inter-American Court of Human Rights (Official Summary of Advisory Opinion OC-23/17 of 15 November 2017) 2; Inter-American Court of Human Rights (Advisory Opinion OC-23/17 of 15 November 2017) 21-22.

142 Inter-American Court of Human Rights (Official Summary of Advisory Opinion OC-23/17 of 15 November 2017) 3 . 
includes ensuring that actions occurring within a State's boundaries do not result in human rights violations from environmental harm occurring outside the State's territory. ${ }^{143}$ On State obligations arising under the rights to life and personal integrity in the Convention, the Court concluded that:

- States have the obligation to prevent significant environmental damage, within or outside their territory;

- States must act in accordance with the precautionary principle, for the purposes of protecting the right to life and personal integrity, against possible serious or irreversible damage to the environment, even in the absence of scientific certainty;

- States must regulate, and supervise the activities under their jurisdiction that may cause significant damage to the environment; carry out environmental impact studies when there is a risk of significant damage to the environment; establish a contingency plan, in order to have security measures and procedures to minimize the possibility of major environmental accidents; and mitigate significant environmental damage that would have occurred, even if it had occurred despite preventive actions by the State;

- States have the obligation to cooperate, in good faith, for protection against damage to the environment;

- States must notify the other potentially affected States when they become aware that a planned activity under their jurisdiction could generate a risk of significant transboundary damage and in cases of environmental emergencies, as well as to consult and negotiate, in good faith, with States potentially affected by significant transboundary harm;

- States have the obligation to guarantee the right to access information related to possible effects on the environment;

- States have the obligation to guarantee the right to public participation of the persons under their jurisdiction; and

- States have the obligation to guarantee access to justice, in relation to the State obligations for the protection of the environment that have been previously stated in the Opinion. ${ }^{144}$

\subsection{Litigation under Domestic Human Rights Laws}

National human rights commissions can also investigate the impact of climate change on human rights. In National Inquiry on the Impact of Climate Change on

\footnotetext{
143 Ibid.

144 Inter-American Court of Human Rights (Advisory Opinion OC-23/17 of 15 November 2017) 95-96.
} 
the Human Rights of Filipino People, ${ }^{145}$ a public interest petition was lodged on 12 May 2015 with the Philippines Commission on Human Rights requesting that it investigate the responsibility of 50 large multinational, publicly traded fossil fuel producing corporations for contributing to climate change and thereby allegedly violating various fundamental human rights of the Filipino people. It is alleged that these 50 corporations account for $21.71 \%$ of total cumulative carbon dioxide emissions between 1751 and 2010. The petitioners are human rights groups, typhoon victims and other concerned citizens. $^{146}$ On 4 December 2015, the Commission announced the commencement of the above inquiry and, by 27 July 2016, the Commission had furnished these 47 'carbon majors' with the petition seeking a response within 45 days. ${ }^{147}$ Hearings in the Philippines commenced on 28 March 2018. In his opening statement, the Chairperson of the Commission, Jose Luis Martin 'Chito' Gascon, remarked: 'Among those who are suffering the most from the effects of climate change is the Philippines. Nowhere has it been more dramatically demonstrated than in November of 2013, when our country was visited by Typhoon Haiyan or Yolanda.'148 The Commission is expected to release its resolution in early 2019, which may contain recommendations for local and international agencies and a model law to address climate change that could be applied globally. According to Commissioner Roberto Cadiz, who is the Chair of this inquiry, damages cannot be awarded in the course of the inquiry, however the results may be relied on as a foundation for filing subsequent cases. ${ }^{149}$

\footnotetext{
145 Commission on Human Rights-Philippines, CHR-NI-2016-0oo3.

146 Philippines Commission on Human Rights, 'CHR to Conduct First Hearing Investigating Possible Contribution of Carbon to Climate Change and its Impact on Human Rights' (26 March 2018) <http://chr.gov.ph/chr-to-conduct-first-hearing-investigating-possiblecontribution-of-carbon-to-climate-change-and-its-impact-on-human-rights/>.

147 J Vidal, 'World's Largest Carbon Producers Face Landmark Human Rights Case' Guardian (28 July 2016) <https://www.theguardian.com/environment/2016/jul/27/worlds-largestcarbon-producers-face-landmark-human-rights-case $>$.

148 Philippines Commission on Human Rights, 'PHL at the forefront of seeking climate justice with CHR's landmark inquiry on the effects of climate change to human rights' (28 March 2018) <http://chr.gov.ph/phl-at-the-forefront-of-seeking-climate-justice/>.

149 NC Lagrimas, 'CHR Sets 2019 Target for Results of Landmark Rights-Based Climate Change Probe' GMA News (12 December 2017) <http://www.gmanetwork.com/news/ news/nation/636263/chr-sets-2019-target-for-results-of-landmark-rights-based-climatechange-probe/story/>.
} 
At the heart of much of the recent climate change litigation is a call for climate justice. Climate change affects everyone, but it disproportionately affects those who have contributed the least to climate change and those least well placed to respond to the impacts of climate change, including those in developing countries and vulnerable peoples everywhere. In contrast, those who have contributed most to climate change-the enterprises and people with the largest carbon footprints, mainly in the developed countries-are most insulated from climate change and its consequences by their wealth and access to resources. ${ }^{150}$ The response to climate change involves both the mitigation of greenhouse gas emissions that contribute to climate change (by reducing sources and increasing sinks) and adaptation to the impacts of climate change. Striking the right balance between mitigation and adaptation is itself a justice issue. To take strong mitigation now is to limit the need for adaptation in the future. To be weaker on mitigation now is to increase the need for future adaptation. At each end, and along, this mitigation-adaptation spectrum are issues of justice in terms of the distribution of environmental benefits and burdens, the procedure for policy and decision making and the recognition given to different people and communities. ${ }^{151}$ Climate change and the response or lack of response of governments to take effective mitigation and adaptation action adversely affect people's rights. The rights include fundamental rights, such as rights to life, liberty or property; particular environmental rights, such as a right to a quality environment; and a right to access and use communal natural resources held under the public trust. The adverse effects on people's rights exacerbate existing inequities and injustices. Climate change litigation is increasingly invoking rights to expose and remedy these inequities and injustices.

This article has surveyed climate change litigation around the world that has invoked rights under the public trust doctrine, constitutional rights, including the right to life and right to a quality environment, and human rights. It reveals how climate change litigation has adapted rights-based claims made in earlier, more traditional litigation to meet the social and environmental crises caused by climate change. The litigation has expanded the content of traditional categories of legal claims and causes of action and the circumstances

150 International Bar Association, Achieving Justice and Human Rights in an Era of Climate Disruption (2014) 2.

151 BJ Preston, "The Adequacy of the Law in Achieving Climate Justice-Some Preliminary Comments' (2016) 34(1) Journal of Energy \& Natural Resources Law 45. 
in which these categories of claims and causes of action are applied. The first and most important category is the expansion of the right to life or right to dignity to include a right to a clean and healthy environment capable of sustaining a quality life. The second category is the expansion of the right not to be deprived of life, liberty or property without due process of law to include a substantive right to a stable climate. The third category is the expansion of the communal natural resources held under public trust to include the atmosphere and the expansion of the government's fiduciary duties to include the duty to protect the atmosphere from climate change. In these ways, climate change litigation is leading to an evolution in rights-based litigation. Rightsbased climate change litigation is also having a globalisation effect. Claims and arguments made in one jurisdiction are being adapted and applied in other jurisdictions. There is a geographical spreading of rights-based climate change litigation. This trend in the evolution and expansion of rights-based climate change litigation shows every sign of continuing. 